\title{
THE ROLE OF ANTICIPATORY SOCIALIZATION AS A MEDIATING VARIABLE BETWEEN THE BIG FIVE PERSONALITY TRAITS AND PROFESSIONAL SKEPTICISM
}

\author{
Tresna Adinda Regbiyantari ${ }^{\prime}$, Niluh Putu Dian Rosalina Handayani Narsa ${ }^{*}$ \\ 'Department of Accounting, Faculty of Economics and Business, Universitas Airlangga \\ Address : ' Jl. Airlangga 4-6, Surabaya, Indonesia 60286 \\ *E-mail : niluh.narsa@feb.unair.ac.id
}

\begin{abstract}
This study analyzes the relationship between the Big Five personality traits and professional skepticism, between professional skepticism and anticipatory socialization, and the relationship between the Big Five personality traits and anticipatory socialization using professional skepticism as the mediating variable. The research data were obtained from 187 questionnaires distributed to accounting students. The results in this study prove that there is a positive relationship between the characteristics of extraversion, agreeableness, conscientiousness, and openness, on anticipatory socialization. Meanwhile, the character of neuroticism has no relationship with anticipatory socialization. In addition, it was also found that there was an indirect, positive relationship between neuroticism, extraversion and conscientiousness, and anticipatory socialization through professional skepticism. This research is expected to provide insights for accounting students as they start preparing to become good auditors while in college.
\end{abstract}

Keywords:Big five personality traits, personality characteristics, professional skepticism, anticipatory socialization.

JEL Classification: M12, M41, M42

Article History:

Received: April 6, 2021; Revised : April 16, 2021; Accepted : April 16, 2021; Available Online : April 26,2021 DOI: $10.20473 / \mathrm{imtt} . \mathrm{v} 14 \mathrm{il} .26228$

\section{INTRODUCTION}

Personal factors, such as personality type and audit experience, are thought to influence auditors' professional skepticism (Aminudin et al., 2016). Certain personalities that auditors have can influence the degree (low or high level) of professional skepticism (Larimbi et al., 2017). Therefore, personality is an important factor in the research. Then, professional skepticism is considered an important component in auditing financial statements (Alnafisah, 2019). Accounting Standards in Indonesia, as well as internationally, emphasize the importance of professional skepticism and define it as an attitude that is often questioning and becomes alert to conditions that may indicate possible errors due to fraud, and which makes a critical assessment of audit evidence (AAIPI, 2013).

Auditor errors in detecting fraud have been demonstrated by several cases of fraud in public accountants such as Xerox (2001), Enron (2001), World Com (2002), Tyco (2002), and, most recently, the case of Walt Disney (2017) which all occurred in the United States of America. Besides, there have also been cases in Indonesia, namely Kimia Farma and several banks 


\section{Tresna Adinda Regbiyantari Niluh Putu Dian Rosalina Handayani Narsa}

whose operations have been frozen (Indonesian acronym: BBO) involving public accountants in Indonesia, as well as the case of the 2019 financial statements of PT Garuda Indonesia Tbk. by well-known firm KAP Ernst and Young Global Limited. Noviyanti (2008) stated that there were 45 cases of fraud that occurred in financial statements, 24 cases (or $60 \%$ of them) arose because of the low level of professional skepticism, therefore a lack of professional skepticism could lead to failure to find fraud in financial statements.

This study uses the Big Five personality traits which are personality characteristics that include all the traits in an individual (Barrick and Mount, 2005). The five major personality types have the characteristics of extraversion, agreeableness, conscientiousness, neuroticism, and openness to experience (Ayu et al., 2015).

Personality characteristics are long-term factors that must be known before entering the work environment, therefore this study uses a sample of undergraduates studying accounting (Brody et al., 2020). Accounting students are trained to enter careers in accounting, especially as auditors, after completing their studies. In connection with these problems, students need anticipatory socialization.

This research will be conducted on students from the class of 2016 who are in their final year majoring in accounting at Airlangga University and who have taken the Introduction to Auditing Practice course. The reason for choosing final year students is because they already have a plan or have thought about what profession to enter after graduating (Gebreiter, 2019). Accounting students have a greater opportunity to prepare themselves to become auditors, so it is necessary to conduct anticipatory socialization /Clikeman and Henning, 2000).

This has been reinforced by research conducted by Winantyadi and Waluyo (2014) states that there is a positive relationship between ethics and the professional skepticism of auditors. The same thing has also been found in research conducted by Farag and Elias (2016) that identified a positive relationship between personality characteristics and professional skepticism. This research also shows that students who have positive personality characteristics and high skepticism tend to be successful auditors. Research conducted by Idawati (2019) also states that there is a positive relationship between professional skepticism and detection of fraud.

However, there are research results that contradict some of the studies above. Research conducted by Suryandari et al. (2017) showed that personality type has no effect on professional skepticism, and it went on to explain that every auditor, regardless of personality 
type, must conduct an audit using the standards that have been set including professional skepticism. Thus, personality type does not play a big role in the professional skepticism that every auditor must exhibit. Other conflicting results found in the study by Aminudin et al. (2016) which obtained results that state that personality type is negatively related to the ability of auditors to detect fraud through professional skepticism: This is because auditors can maintain skepticism in performing their audit tasks.

Gaps in the research arise due to there being differences like these between results from one study and another study even with the same concept. There are inconsistencies according to previous studies, so this study has added professional skepticism as a mediator for the relationship between the Big Five personality traits and anticipatory socialization. Professional skepticism is thought to support the increase in someone's anticipatory socialization. In research by Rohman (2017), professional skepticism is considered to be a mediator because it is an important attitude in terms of the achievement of becoming a professional auditor.

The purpose of this study is to examine the relationship between the Big Five personality traits and anticipatory socialization with professional skepticism as a mediating variable. The findings from this study show that the characteristics of extraversion, conscientiousness, neuroticism, and openness have a positive relationship with professional skepticism among students who are prospective auditors. Meanwhile, agreeableness has no relationship with professional skepticism. Positive characteristics in individuals can produce high levels of professional skepticism. The results of research on the relationship between professional skepticism and anticipatory socialization show positive results. Furthermore, a mediation relationship was also found between the characteristics of extraversion, conscientiousness, and neuroticism with anticipatory socialization through professional skepticism.

From a theoretical point of view, the results of this study contribute by continuing the research by Farag and Elias (2016) which seeks to describe the extent and nature of professional skepticism among accounting students and to identify certain personality characteristics to introduce into the training on auditing and shows that students with a high level of skepticism have high levels of anticipatory socialization experience. However, Farag and Elias (2016) do not raise professional skepticism as a mediating variable. This study predicts that professional skepticism can explain the mechanism behind the relationship between Big Five personality traits and anticipatory socialization. Aminudin et al. (2016) state that professional skepticism can mediate an auditor's behavior about detecting fraud, so the logic of their study is in line with what is raised by this study. Therefore, this study adds professional skepticism as a mediating variable. 


\section{Tresna Adinda Regbiyantari Niluh Putu Dian Rosalina Handayani Narsa}

From a practical point of view, this study is expected to broaden the knowledge of those final year accounting students who wish to be involved in the world of auditing to develop their professional skepticism starting from their time at college so that they can prepare themselves to become good auditors. The next section of this article will describe the hypothesis development, research methods, research results, and finish with conclusions and suggestions.

\section{LITERATURE REVIEW AND HYPOTHESES}

\section{The Relationship between The Big Five Personality Traits and Professional Skepticism}

One of the variables that can be an indicator that determines a person's performance is personality. Personality is the basis of a person's existence as an individual in determining their skeptical behavior and it is closely related to the level of professional skepticism. Mccrae and Costa (1990) introduced a model of personality characteristics called the Big Five Personality Traits consisting of extraversion, agreeableness, conscientiousness, neuroticism, and openness.

Based on previous research conducted by Farag and Elias (2016) on the Big Five personality traits, it is predicted that there is a relationship between each characteristic and the attitude of professional skepticism among accounting students. Extraversion is predicted to have a positive relationship with professional skepticism because extraversion is a pleasure-seeking trait; extroverts also tend to look for problems and are skeptical as they do their work (De Bruin and Rudnick, 2007). Agreebleness is predicted to have a positive relationship with professional skepticism because aggreeable individuals think that dishonesty will have a negative impact on those who use financial statements (Clariana, 2013) so this individual will have high skepticism in conducting audits. Like extraversion and agreeableness, conscientiousness is also predicted to have a positive relationship with professional skepticism. The characteristic of conscientiousness means a person is careful and wants to do their best in their work (Steel, 2007) and professional skepticism is very important for the success of the auditing process. On the other hand, neuroticism is predicted to have a negative relationship with professional skepticism because individuals who have this characteristic prefer to avoid problems and escape from stress (Carver and Smith, 2010), therefore they tend to have low professional skepticism to avoid pressure. Finally, openness is predicted to have a positive relationship with professional skepticism because these individuals tend to be very critical and thoughtful about the findings they get (Mccrae and Costa, 1997), therefore they will have high skepticism. 
A similar study was conducted by Rustiarini (2013) who used the personality traits of extraversion, conscientiousness, neuroticism, agreeableness, and openness. The results show that only conscientiousness, extraversion, and neuroticism have a relationship with the performance of an auditor, while the characteristics of agreeableness and openness have no relationship with auditor performance. The same has been done in the research conducted by Ayu et al. (2015) which states that personality characteristics influence professional skepticism. The study found that extraversion and agreeableness variables have a positive effect on auditor performance, while the variables of conscientiousness, neuroticism, and openness to experience do not affect on auditor performance. Research by Noviyanti (2008) examines the effect of personality characteristics on professional skepticism. The characteristics used are a combination of 'Sensing-Thinking' (ST) and 'Intuitive-Thinking' (IT). The results of this study indicate that auditors with personality types ST and NT have a high level of professional skepticism compared to other personality combinations.

Cognitive dissonance theory is a social psychology theory that discusses feelings of discomfort in individuals due to conflicting behaviors, attitudes and thoughts, and how this motivates individuals to make changes because of their discomfort. In practice, auditors will often experience a problem when carrying out an audit assignment (Khan and Harding, 2020). This can be attributed to cognitive dissonance theory. The concept of cognitive dissonance explains that if there is a dissonance, students, as auditors, must try to change the dissonance and instead achieve consonance by changing their attitudes and behavior. One of them is the characteristic of neuroticism; this characteristic makes a person prefer to avoid problems and escape from stress. If one becomes an auditor, of course, this will cause dissonance, so students as auditors will reduce this attitude by changing their behavior to achieve consonance. Thus, the hypothesis that can be formulated is as follows:

$\mathrm{H}_{1 \mathrm{a}}$ : The personality characteristics of extraversion, agreeableness, conscientiousness, and openness have a positive relationship with professional skepticism.

$H_{1 b}$ : The personality characteristic of neuroticism has a negative relationship with professional skepticism.

\section{The Relationship between Professional Skepticism and Anticipatory Socialization}

Anticipatory socialization is the stage that occurs during the undergraduate study period. Anticipatory socialization can help students develop the behavior needed to become good auditors. So it can be said that the anticipatory socialization that develops while studying is an important stage in the student preparation process before entering a professional work environment. 


\section{Tresna Adinda Regbiyantari Niluh Putu Dian Rosalina Handayani Narsa}

Differences in the level of knowledge about something can affect each individual's attitude towards it, and this attitude will affect that person's intentions (Ismail and Yuhanis, 2018). It is the same in the accounting profession, where different levels of knowledge regarding the professional code of ethics, rules, and laws will affect the attitude one chooses to use to judge something, for example in cases of fraud. Therefore, it is important to develop anticipatory socialization - and even engage in it- before individuals enter a professional work environment.

Accounting students who have a high level of anticipatory socialization will also have a high level of understanding about what rules exist in their desired profession. This is carried out so that later, when they enter the professional work environment, they do not violate the code of ethics, especially in the auditing profession. High anticipatory socialization also determines that the students see acts of cheating. In avoiding this fraud, accounting students will tend to understand the importance of professional skepticism. Based on this, the anticipatory socialization variable in this study is related to the perception of the importance of professional skepticism in examining financial reports. It is expected that students having a high level of professional skepticism will influence their quality in order to become successful auditors (as has been proven by positive perceptions of the importance of financial reports for stakeholders).

Previous research conducted by Farag and Elias (2016) has found a positive relationship between the anticipatory socialization of accounting students and professional skepticism. Ahmad et al. (2012) also argue that the level of anticipatory socialization among accounting students results in a positive relationship with professional commitment. Positive results related to anticipatory socialization indicate that accounting education provides a higher understanding of the importance of financial reports for external stakeholders. The results of research conducted by Mahmudah (2018) on anticipatory socialization and the intention to engage in whistleblowing, show that there is a positive relationship between these variables, meaning that the higher the level of anticipatory socialization of accounting students, the higher the intention to engage in whistleblowing. Research related to this has also been conducted by Elias (2008). The results of this study indicate that the level of students' anticipatory socialization has a positive relationship with the intention to engage in whistleblowing.

The basic theory of cognitive dissonance can help explain why the attitude of auditors is skeptical when they feel there is dissonance when they detect fraud (Noviyanti, 2008). The level of student anticipatory socialization will increase in line with an increasing level of professional skepticism. In other words, cognitive dissonance can occur if accounting 
students do not increase their anticipatory socialization. Thus, the hypothesis that can be formulated is as follows:

\section{$\mathrm{H}_{2}$ : Professional skepticism has a positive relationship with anticipatory socialization.}

\section{The Relationship between Big Five Personality Traits and Anticipatory Socialization}

The basis of the cognitive dissonance theory shows that people will basically try not to enter into situations which they think are risky, and they will enter into situations that they think are comfortable instead. This behavior can be influenced by the way a person understands what action is taken next (Kushasyandita, 2012). Anticipatory socialization can be a solution for accounting students so that they develop behaviors from their personality characteristics that they consider will address risks to the professional world of auditors later. Therefore, the right anticipatory socialization can produce behavior based on good personality and can answer existing cognitive dissonance problems.

A person's personality is the basis of their existence as an individual. This factor is one of the determinants of a person's behavior when taking action. Therefore, socialization can make someone understand how to behave during a work environment later. Anticipatory socialization also shapes individuals to be able to adapt to the existing ethics and be able to understand existing regulations. Anticipatory socialization is the process of forming a person's personality characteristics to understand how his or her position is in the work environment. The social environment in the world of auditors has a code of ethics to avoid fraud at work; this can influence a person to discourage committing fraud.

Previous research by Farag and Elias (2016) has sought to demonstrate how personality characteristics are related to the level of anticipatory socialization of students. This study predicts a positive relationship between the personality characteristics of extraversion, agreeableness, conscientiousness, and openness, and anticipatory socialization. These positive characteristics explain that curiosity about something new is very high so it is predicted to have a positive relationship with anticipatory socialization. Meanwhile, neuroticism is a negative characteristic in an individual. This characteristic has unstable emotions and makes one prone to experience stress in certain situations so this characteristic is predicted to have a negative relationship with anticipatory socialization.

Research conducted by Li et al. (2014) shows that there is a positive relationship between anticipatory socialization and the top five personality types. These results suggest that anticipatory socialization is broadly beneficial for a person's characteristics. The same results have also been found by Lämsä et al. (2008) who show that business students with higher levels of anticipatory socialization have better understanding compared to other employees 
who have low levels of anticipatory socialization. In research by Abdolmohammadi (2003) also stated that there is a positive relationship between anticipatory socialization and shaping one's thinking about ethical orientation before entering the professional world. Then Elias (2006) have also found that the results of anticipatory socialization have a positive relationship with ethical orientation in individuals.

It is predicted that individuals who are good at socializing and interacting will obtain-and know-a lot of information about a person's personality types. The more someone socializes, the more they will choose which group is most appropriate for them. Therefore, the higher the level of anticipatory socialization of the individual. Based on the above explanation, a hypothesis can be formulated as follows:

$\mathrm{H}_{3 \mathrm{a}}$ : The characteristics of extraversion, agreeableness, conscientiousness, and openness have a positive relationship with anticipatory socialization.

$\mathrm{H}_{3 b}$ : The characteristic of neuroticism has a negative relationship with anticipatory socialization

The Relationship between The Big Five Personality Traits and Anticipatory Socialization where Professional Skepticism is a Mediating Variable

Professional skepticism is an important component for accounting students who must be prepared to enter the profession. Ardts et al. (2001) identify this preparation as an anticipatory stage that occurs during the period of undergraduate studies. This phase is considered to be a preparation phase before students enter a professional work environment. Anticipatory socialization can help students develop the behavior needed to become good auditor. Palaiou and Furnham (2014) compare the personality characteristics of CEOs and managers in U.K. companies. The study finds that CEOs' personality characteristics in terms of extraversion, agreeableness, and conscientiousness, outperformed the professional managers, but this was the other way around for neuroticism. Although there has been no such research conducted on accounting students, the researchers contend that it is permissible to assume that professionals in the field of accounting are also reflected in professionals in business in general, including when they are still at the student stage (Farag and Elias, 2016).

The Big Five personality traits have an important role in forming a person's level of anticipatory socialization, and having to have professional skepticism is one of the factors behind an auditor being good later. Professional skepticism can influence a person's intention to conduct anticipatory socialization based on their personality characteristics (Farag and Elias, 2016). 
The results of previous studies indicate that a person's personality characteristics are related to performance, where conscientiousness and neuroticism are negatively related to one's performance in all occupations. Meanwhile, extraversion, agreeableness, and openness can be predictors of performance at work related to one's or social interactions (Rothmann and Coetzer, 2003). Elias (2008) has found that accounting students with a high level of anticipatory socialization will engage in whistleblowing if there is fraud.

On the other hand, there are conflicting results from Aminudin et al. (2016), who have found that personality characteristics are negatively related to the ability of auditors to detect fraud through professional skepticism. This is because auditors can maintain skepticism in performing their audit tasks. Given these conflicting findings, it is important to use professional skepticism as a mediating variable that may explain the mechanism behind it.

In the professional world, auditors will experience cognitive dissonance if they have personality characteristics with a high level of trust in their clients; this can lead to low professional skepticism. Dissonance occurs when auditors who overly trust their clients will contribute to the level of fraud in the audit being higher, therefore auditors are required to have professional skepticism (Agustin, 2020). Therefore, the dissonance in the world of auditing can change if accounting students change their behavior, based on their personality characteristics, so that they have professional skepticism. So, before that, students need to learn all the lessons about what must be prepared to become a good auditor. Thus, the hypothesis that can be formulated is as follows:

$\mathrm{H}_{4 a}$ : Extraversion, agreeableness, conscientiousness, and openness have a positive relationship withanticipatory socialization, and professional skepticism is a mediating variable.

$\mathrm{H}_{4 b}$ : Neuroticism has a negative relationship with anticipatory socialization, and professional skepticism is a mediating variable.

\section{RESEARCH METHODS}

This study uses a quantitative research approach with associative research methods. Respondents in this study were final-year accounting students at Airlangga University. The researchers chose Airlangga University accounting students as the study's population for several reasons, the first being that the researchers are working in that environment, and their accounting students have thought about or plan to enter the profession after completing their studies and are considered to have sufficient knowledge to become auditors (Elias, 2008). Then, the major in accounting offered by Airlangga University is one of the best accounting courses in Surabaya and has obtained a grade A accreditation from BAN-PT (National Accreditation Board for Higher Education). Furthermore, accounting students who 


\section{Tresna Adinda Regbiyantari Niluh Putu Dian Rosalina Handayani Narsa}

enter their final semester have taken the Introduction to Audit Practice course and so are considered to have sufficient knowledge of professional skepticism meaning they are suitable as research subjects. A total of 250 questionnaires were distributed and only 187 could be further processed. Ethics approval from the committee in this study was not required because all of the respondents provided written informed consent before enrolment in the study to answer all of the questions in the questionnaire used.

The independent variables in this study are the Big Five personality traits and professional skepticism, while the dependent variable is anticipatory socialization. This study has also used control variables in the form of gender and age. The Big Five personality traits are personality characteristics that comprise a model that summarizes several human traits (Barrick and Mount, 2005). The indicators used to measure a person's top five personality characteristics were adopted from the research of Donnellan et al. (2006) entitled The Mini-IPIP Scales: TinyYet-Effective Measures of the Big Five Factors of Personality.

Professional skepticism is behavior consisting of thoughts that are always questioning, that are alert to circumstances and conditions that are likely to be misstatements or errors caused by someone's mistake or deliberate action, and also critical assessment of audit evidence (IAASB, 2013). The indicators of professional skepticism consist of thirty questions adopted from the research of Hurtt (2010) entitled Development of a Scale to Measure Professional Skepticism.

Finally, to measure anticipatory socialization, the researchers adopt indicators used in the study conducted by Clikeman and Henning (2000) entitled The Socialization of Undergraduate Accounting Students. The term anticipatory socialization is defined as the outcome that has been prepared from all the learning carried out by someone before entering the professional world (Larasati, 2018)). Anticipatory socialization has a long-term effect on a person and creates positive opinions about an individual's commitment to a profession.

All question items are measured using the interval measurement Likert scale technique, starting from point 1 (strongly disagree) to point 5 (strongly agree). A 5-point Likert scale is used in this study because it can produce results with strong reliability and a high validity index for the study (Aquaculture, 2020). The data analysis method used is the WarpPLS version 5.0 software. PLS (Partial Least Square). 


\section{RESULTS AND DISCUSSION}

\section{Description of Results}

Of the 187 respondents whose data could be further processed, $34 \%$ were male. Respondents' ages ranged from 20 to 24 years with the following distribution: 1.5\% were 20 years old, $22 \%$ were 21 years old, $66 \%$ were 22 years old, 10\% were 23 years old, and the rest were 24 years old. Table 1 shows the descriptive answers of respondents for all statements regarding the Big Five personality traits research variables consisting of Extraversion (E), Agreeableness (A), Conscientiousness (C), Neuroticism (N), and Opennes / Intellect (O). It also shows the descriptive answers of the respondents for each statement regarding the variables of professional skepticism and anticipatory socialization.

Table 1.

Respondents' Descriptive Answers

\begin{tabular}{|c|c|c|c|}
\hline Variable & Item & Mean & Standard Deviation \\
\hline \multirow{20}{*}{ Big Five Personality Traits } & El & 3.34 & 0.87 \\
\hline & Al & 4.33 & 0.62 \\
\hline & $\mathrm{Cl}$ & 3.66 & 0.99 \\
\hline & $\mathrm{N} 1$ & 3.54 & 1.16 \\
\hline & 01 & 4.00 & 0.86 \\
\hline & E2 & 3.24 & 1.08 \\
\hline & A2 & 3.32 & 1.02 \\
\hline & $C 2$ & 2.90 & 1.24 \\
\hline & N2 & 3.06 & 1.00 \\
\hline & $\mathrm{O} 2$ & 2.79 & 1.07 \\
\hline & E3 & 3.44 & 1.06 \\
\hline & A3 & 4.06 & 0.77 \\
\hline & C3 & 4.10 & 0.77 \\
\hline & N3 & 3.29 & 1.15 \\
\hline & O3 & 3.01 & 1.01 \\
\hline & $\mathrm{E} 4$ & 3.68 & 0.97 \\
\hline & A4 & 2.81 & 1.01 \\
\hline & C4 & 2.45 & 1.09 \\
\hline & N4 & 2.80 & 1.00 \\
\hline & $\bigcirc 4$ & 2.39 & 1.03 \\
\hline \multirow[t]{15}{*}{ Professional Skepticism } & PS1 & 2.65 & 1.01 \\
\hline & PS2 & 3.83 & 0.89 \\
\hline & PS3 & 4.21 & 0.71 \\
\hline & PS4 & 4.09 & 0.78 \\
\hline & PS5 & 3.97 & 0.88 \\
\hline & PS6 & 4.05 & 0.86 \\
\hline & PS7 & 3.82 & 0.86 \\
\hline & PS8 & 4.46 & 0.62 \\
\hline & PS9 & 4.33 & 0.71 \\
\hline & PS10 & 2.77 & 0.92 \\
\hline & PS 11 & 2.78 & 0.80 \\
\hline & PS 12 & 3.51 & 1.03 \\
\hline & PS13 & 3,72 & 0,87 \\
\hline & PS14 & 4,10 & 0,79 \\
\hline & PS 15 & 3,86 & 0,92 \\
\hline
\end{tabular}




\begin{tabular}{cccc}
\hline Variable & Item & Mean & Standard Deviation \\
\hline & & & \\
PS16 & 2,65 & 0,94 \\
PS17 & 2,61 & 1,08 \\
PS18 & 3,60 & 0,76 \\
PS19 & 3,19 & 0.81 \\
PS20 & 3,75 & 0,89 \\
PS21 & 3,76 & 0,99 \\
PS22 & 4,22 & 0,68 \\
PS23 & 3,96 & 0,78 \\
PS24 & 4,07 & 0,71 \\
PS25 & 2,87 & 0,92 \\
PS26 & 2,67 & 0,93 \\
PS27 & 4,19 & 0,67 \\
PS28 & 4,12 & 0,75 \\
PS29 & 3,88 & 0,86 \\
PS30 & 3.95 & 0.80 \\
AS1 & 4.09 & 0.73 \\
AS2 & 3.67 & 1.01 \\
& AS3 & 3.02 & 1.04 \\
AS4 & 4.05 & 0.77 \\
AS5 & 2.83 & 1.12 \\
& AS6 & 3.37 & 1.07 \\
AS7 & 3.16 & 1.17 \\
AS8 & 3.70 & 1.00 \\
AS9 & 2.14 & 1.11 \\
AS10 & 3.45 & 1.19 \\
AS11 & 3.96 & 0.71
\end{tabular}

Source: Research data, processed 2020

Table 2.

AVE Values and Reliability

\begin{tabular}{lcl}
\hline \multicolumn{1}{c}{ Variable } & $\begin{array}{c}\text { Average VarianceValue } \\
\text { (AVE) }\end{array}$ & Composite Reliability \\
\hline Extraversion & 0.746 & 0.855 \\
Agreeableness & 0.721 & 0.838 \\
Conscientiousness & 0.704 & 0.827 \\
Neuroticism & 0.782 & 0.878 \\
Openness & 0.577 & 0.803 \\
Professional Skepticism & 0.537 & 0.912 \\
Anticipatory Socialization & 0.560 & 0.792 \\
\hline
\end{tabular}

Source: Research data, processed 2020

According to the results of Table 2, the AVE value in all variables is $>0.5$. Therefore, it can be concluded that all variables are declared to be valid. After that, the reliability test is carried out on all the variables used in this study which shows the result that all variables have a composite reliability value $>0.70$. These results illustrate that all variables used are feasible and reliable to be used in this research process.

\section{Hypothesis Test Results and Discussion}

Hypothesis testing in this study was conducted by testing the direct relationship hypothesis and indirect relationship hypothesis. The direct relationship hypothesis test aims to determine 
the relationship between the Big Five personality traits and professional skepticism, the relationship between professional skepticism on anticipatory socialization, and the relationship between the Big Five personality traits and anticipatory socialization. Hypothesis testing uses the t-statistic test in the partial least square (PLS) analysis model with the help of the WarpPLS 5.0 software. Meanwhile, the indirect relationship test is carried out using the indirect effect estimation simultaneously with the triangle partial least square (PLS) model. The results of hypothesis testing in this study can be seen in Table 3 as follows below.

The test results on the $\mathrm{H}_{1 a}$ hypothesis show that extraversion, conscientiousness, and openness are positively related to professional skepticism. Meanwhile, the agreeableness personality characteristic has no relationship with professional skepticism. This study explains that accounting students who have an extraversion attitude can look for a problem and be skeptical in their work. Accounting students who exhibit the characteristic of conscientiousness are people who want to do their best in their work and they consider professional skepticism to being very important for an audit to be conducted successfully. Individuals with the characteristic of openness are very critical and thoughtful about their audit findings. The results of this research hypothesis test are supported by previous research by Rustiarini (2013) which uses personality traits of extraversion, conscientiousness, neuroticism, agreeableness, and openness. Meanwhile, individuals with the characteristic of agreeableness are individuals who have a high sense of empathy for others, and who can feel other people's emotions regarding other problems so they have no relationship to professional skepticism. Then, the $\mathrm{H}_{1 b}$ test results show that neuroticism has a positive relationship with professional skepticism. The results of this hypothesis test found that emotional stability will not affect one's professional skepticism. These results are in line with research conducted by Ayu et al. (2015) who find that emotional stability has no relationship with auditors' performances in detecting fraud. This is because, if an auditor has the very low emotional stability, and if it is related to professionalism, they will still be able to control their emotions when facing serious situations during an assignment, so these characteristics will not affect the auditor's performance later (Siew Siew et al., 2018).

Table 3.

Hypothesis Test Results

\begin{tabular}{ccc}
\hline & Direct Relationship & \\
\hline Relationship Between Variables & Path Coefficient & P-Value \\
\hline E $\rightarrow$ PS & 0.329 & $<0.001$ \\
A $\rightarrow$ PS & 0.083 & 0.125 \\
C $\rightarrow$ PS & 0.255 & $<0.001$ \\
N $\rightarrow$ PS & 0.250 & $<0.001$ \\
PS & 0.141 & 0.024 \\
PS $\rightarrow$ AS & 0.337 & $<0.001$ \\
\hline
\end{tabular}




$\begin{array}{lll}E \rightarrow \text { AS } & 0.240 & <0.001 \\ \mathrm{~A} \rightarrow \text { AS } & 0.252 & <0.001 \\ \mathrm{C} \rightarrow \text { AS } & 0.121 & 0.047 \\ \mathrm{~N} \rightarrow \text { AS } & 0.068 & 0.175 \\ O \rightarrow \text { AS } & 0.218 & 0.001 \\ G \rightarrow \text { PS } & 0.079 & 0.137 \\ \text { A } \rightarrow \text { PS } & 0.089 & 0.107\end{array}$

Indirect Relationship

\begin{tabular}{ccc}
\hline Relationship Between Variables & Path Coefficient & P-Value \\
\hline$E \rightarrow P S \rightarrow$ AS & 0.111 & 0.015 \\
$\mathrm{~A} \rightarrow$ PS $\rightarrow$ AS & 0.028 & 0.293 \\
C $\rightarrow$ PS $\rightarrow$ AS & 0.086 & 0.046 \\
$N \rightarrow$ PS $\rightarrow$ AS & 0.084 & 0.050 \\
$O \rightarrow$ PS $\rightarrow$ AS & 0.048 & 0.177 \\
\hline
\end{tabular}

Source: Research data, processed 2020

The second hypothesis $\left(\mathrm{H}_{2}\right)$ shows that the professional skepticism variable is positively related to anticipatory socialization. This indicates that students with a high level of anticipatory socialization will have a good understanding of what the rules stipulate to be allowed and disallowed by their profession, and they will have an understanding of what can violate their professional code of ethics (Willie, 2020). The results of this study are in line with previous research conducted by Ahmad et al. (2012) who argue that the level of anticipatory socialization among accounting students results in a positive relationship with professional commitment.

The $\mathrm{H}_{3 a}$ test results indicate that the characteristics of extraversion, agreeableness, conscientiousness, and openness have a positive relationship with anticipatory socialization. Meanwhile, the results of the $\mathrm{H}_{3 b}$ test indicate that the characteristic of neuroticism has no relationship with anticipatory socialization. The results of this research hypothesis test indicate that accounting education has provided sufficient understanding to accounting students with the characteristics of extraversion, agreeableness, conscientiousness, and openness about the importance of financial reports for external stakeholders. Students who have a positive personality have a strong attitude towards anticipatory socialization. Meanwhile, the neuroticism personality characteristic has no relationship. It can be concluded from these results that someone who is prone to feeling nervous, anxious, and insecure, and who has the low emotional stability, has no relationship with high anticipatory socialization (Fajar et al., 2019). 
Then, the $\mathrm{H}_{4 \mathrm{a}}$ test results show that professional skepticism mediates the relationship between the characteristics of extraversion and conscientiousness, and anticipatory socialization. Meanwhile, professional skepticism does not mediate the relationship between agreeableness and openness characteristics, and anticipatory socialization. The $\mathrm{H}_{4 \mathrm{~b}}$ results show that professional skepticism can mediate the relationship between neuroticism characteristics and anticipatory socialization. The results of this study show that professional skepticism can encourage accounting students who have the characteristics of extraversion, conscientiousness, and neuroticism to conduct anticipatory socialization of their personality characteristics and it can foster students' interest in anticipatory socialization. Accounting students who have a high level of professional skepticism related to the world of auditing can encourage students to change their behavior from personality characteristics that are far from being skeptical such as neuroticism to conduct anticipatory socialization (Petry, 2020). Therefore, the results of this study prove that the existence of professional skepticism as a mediating variable in the relationship between neuroticism personality characteristics and anticipatory socialization can produce positive results.

\section{CONCLUSION}

Professional skepticism is considered to be an important component in the auditing of financial statements. Auditor errors in detecting fraud have been demonstrated by several cases where the failure occurred due to a low level of professional skepticism on the part of public accountants and this is the third most frequent deficiency found to occur with audits. It is thought that personal factors such as personality types can influence the auditor's professional skepticism and the way to handle it is through anticipatory socialization. This study used a sample of accounting students because the concept of professional skepticism is first introduced to them when they are carrying out their studies before becoming auditors. The research data were obtained from 187 questionnaires distributed to the accounting students from the class of 2016 at Universitas Airlangga. The data were processed using statistical analysis of Partial Least Square (PLS).

The results of the testing of the first hypothesis show that the Big Five personality traits are positively related to professional skepticism. The results of this hypothesis test found that low emotional stability will not affect one's professional skepticism. This indicates that the Big Five personality traits are, collectively, one of the important factors that can influence accounting students to have high skepticism and become successful auditors. The the testing of the second hypothesis shows that the professional skepticism variable has a positive relationship with anticipatory socialization. This indicates that students with a high level of anticipatory socialization will have a high understanding of what the rules stipulate as being allowed and 


\section{Tresna Adinda Regbiyantari Niluh Putu Dian Rosalina Handayani Narsa}

disallowed by their profession, and they will have an understanding of what violates their professional code of ethics.

The results of the testing of the third hypothesis show that the characteristics of extraversion, agreeableness, conscientiousness, and openness have a positive relationship with anticipatory socialization. Meanwhile, the characteristic of neuroticism has no relationship with anticipatory socialization. The results of this research hypothesis test indicate that accounting education has provided sufficient understanding to accounting students who have the characteristics of extraversion, agreeableness, conscientiousness, and openness regarding the importance of financial reports for external stakeholders. Meanwhile, the neuroticism personality trait has no relationship. From these results, it can be concluded that someone who is prone to feeling nervous, anxious, and insecure, and who has low emotional stability, does not have a strong attitude towards anticipatory socialization. The fourth hypothesis shows that professional skepticism mediates the relationship between the characteristics of extraversion and conscientiousness and anticipatory socialization because there is a significant positive direct and indirect relationship (partial mediation), while professional skepticism also mediates the relationship between neuroticism characteristics and anticipatory socialization because there is no significant relationship in direct tests, but it has a significant relationship in the indirect test (full mediation). The results of this study indicate that professional skepticism can encourage accounting students who have these characteristics to conduct anticipatory socialization of their personality characteristics and can foster students' interest in anticipatory socialization. In the future, it is suggested that research is conducted in more than one university with accounting students in order to compare the characteristics of accounting students from each university. In addition, future research could also explore other mediation variables that are predicted will play a role in explaining attitudes to anticipatory socialization.

\section{REFERENCES}

Abdolmohammadi, M.J., Read, W.J. and Scarbrough, D.P. 2003. Does Selection-Socialization Help to Explain Accountants' Weak Ethical Reasoning? Journal of Business Ethics, 42(1): 71-81.

Agustin, R. 2020. Professional skepticism and the ability of auditor in assessing audit risk. International Journal of Scientific and Technology Research, 9(2): 5479-5483.

Ahmad, Z. Anantharaman, R.N. and Ismail, H., 2012. Students' Motivation, Perceived Environment and Professional Commitment: An Application of Astin's College Impact Model. Accounting Education, 21 (2): 187-208.

Alnafisah, Y.A. 2019. The Practice of Professional Scepticism in Auditing. 
Aminudin, M.R., Suryandari, D. and History, A. 2016. Factors Affecting Auditor's Ability in Detecting Fraud through Professional Scepticism. Accounting Analysis Journal, 5(4): 344-351.

Aquaculture, F. 2020. A Comprehensive Guide for Design, Collection, Analysis and Presentation of Likert and other Rating Scale Data.

Ardts, J., Jansen, P. and Van Der Velde, M. 2001. The breaking in of new employees: Effectiveness of socialisation tactics and personnel instruments. Journal of Management Development, 20(2): 159-167.

Asosiasi Auditor Intern Pemerintah Indonesia, 2013. Standar Audit Intern Pemerintah Indonesia. Asosiasi Auditor Intern Pemerintah Indonesia.

Ayu, I.G., Suardikha, I.M.S. and Budiasih, N. 2015. Pengaruh Big Five Personality Pada Kinerja Auditor Kantor Akuntan Publik Provinsi Bali. Jurnal Ilmiah Akuntansi dan Bisnis: 19-27.

Barrick, M.R. and Mount, M.K. 2005. Yes, Personality Matters: Moving on to More Important Matters. Human Performance, 18.

Brody, R.G., Gupta, G. and White, T. 2020. Whistleblowing in India: evidence from accounting students and professionals. International Journal of Accounting and Information Management, 28(1): 126-146.

De Bruin, G.P. and Rudnick, H. 2007. Examining the cheats: The role of conscientiousness and excitement seeking in academic dishonesty. South African Journal of Psychology, 37(1): 153-164.

Carver, C.S. and Connor-Smith, J. 2010. Personality and Coping. Annual Review of Psychology, 61 (1): 679-704.

Clariana, M. 2013. Personalidad, procrastinación y conducta deshonesta en alumnado de distintos grados universitarios - Personality, procrastination and cheating in students from different university degree programs. Electronic Journal of Research in Educational Psychology, 11 (2): 451-472.

Clikeman, P.M. and Henning, S.L. 2000. The Socialization of Undergraduate Accounting Students. Issues in Accounting Education, 15.

Donnellan, M.B., Oswald, F.L., Baird, B.M. and Lucas, R.E. 2006. The Mini-IPIP scales: Tiny-yeteffective measures of the Big Five factors of personality. Psychological Assessment, 18(2): 192-203.

Elias, R. 2008. Auditing students' professional commitment and anticipatory socialization and their relationship to whistleblowing. Managerial Auditing Journal, 23(3): 283-294.

Elias, R.Z. 2006. The impact of professional commitment and anticipatory socialization on accounting students' ethical orientation. Journal of Business Ethics, 68(1): 83-90.

Fajar Rezekian Noor, Novita WeningTyas Respati and Chairina. 2019. The Effect of Workload, Audit Experience and Audit Risks on the Auditor's Professional Skepticism: A Focus on Indonesia. Restaurant Business, 118(11): 470-477. 
Farag, M.S. and Elias, R.Z. 2016. The relationship between accounting students' personality, professional skepticism and anticipatory socialization. Accounting Education, 25(2): 124-138.

Gebreiter, F. 2019. Making up ideal recruits: Graduate recruitment, professional socialization and subjectivity at Big Four accountancy firms. Accounting, Auditing and Accountability Journal, 33(1): 233-255.

Hurtt, R.K. 2010. Development of a scale to measure professional skepticism. Auditing, 29(1): $149-171$.

Idawati, W. 2019. The Auditor's Ability to Detect Fraud: Gender, Professional Skepticism, and Time Budget Pressure. 73(Aicar 2018): 14-16.

Ismail, S. and Yuhanis, N. 2018. Determinants of ethical work behaviour of Malaysian public sector auditors. Asia-Pacific Journal of Business Administration, 10(1): 21-34.

Khan, J. and Harding, N. 2020. Facilitating the application of auditors' underlying skeptical disposition: The relationship between trait skepticism and basic human values. Accounting Research Journal, 33(1): 34-56.

Kushasyandita, S. 2012. Pengaruh Pengalaman, Keahlian, Situasi Audit, Etika dan Gender terhadap Ketepatan Pemberian Opini Auditor melalui Skeptisisme Profesional Auditor.

Lämsä, A.M., Vehkaperä, M., Puttonen, T. and Pesonen, H.L. 2008. Effect of business education on women and men students' attitudes on corporate responsibility in society. Journal of Business Ethics, 82(1): 45-58.

Larasati, O. 2018. Pengaruh Komitmen Organisasi, Intensitas Moral Dan Sosialisasi Antisipatif Terhadap Tindakan Whistleblowing. Jurnal Mitra Manajemen, 2(4): 273-285.

Larimbi, D., Subroto, B. and Rosidi, R. 2017. Pengaruh Faktor-Faktor Personal Terhadap Skeptisisme Profesional Auditor. EKUITAS (Jurnal Ekonomi dan Keuangan), 17(1): 89.

Li, N., Barrick, M.R., Zimmerman, R.D. and Chiaburu, D.S. 2014. Retaining the Productive Employee: The Role of Personality. Academy of Management Annals, 8(1): 347-395.

Mahmudah, H. 2018. Pengaruh Komitmen Profesi, Sosialisasi Antisipatif Mahasiswa Akuntansi Dan Ethical Climate Principle Terhadap Niat Whistleblowing. Jurnal Ilmiah Ekonomi Dan Bisnis, 15(2): 165-176.

Mccrae, R.R. and Costa, P. 1990. Personality in adulthood. New York: The Guilford Press.

Mccrae, R.R. and Costa, P. 1997. Conceptions and correlates of openness to experience. San Diego, CA: Academic Press.

Noviyanti, S. 2008. Skeptisisme Profesional Auditor Dalam Mendeteksi Kecurangan. Jurnal Akuntansi dan Keuangan Indonesia, 5(1): 102-105.

Nyoman Ayu Suryandari, N. Mahasaraswati Denpasar Bali, U. and Anik Yuesti, I. 2017. Professional Scepticism and Auditors Ability To Detect Fraud Based on Workload and Characteristics of Auditors. Scientific Research Journal (SCIRJ), V(IX): 109.

Palaiou, K. and Furnham, A. 2014. Are Bosses Unique? Personality Facet Differences Between 
Ceos. Consulting Psychology Journal: Practice and Research, 66(3): 173-196.

Petry, T., Treisch, C. and Bullinger, B. 2020. The logic of attraction: exploring the institutional complexity of job preferences. Employee Relations.

Rohman, A. 2017. Developing Improvement of Auditor' S Performance Model Using Professional Skepticism and Auditors ' Comfort as A Mediator. (February 2018).

Rothmann, S. and Coetzer, E.P. 2003. The Big Five Personality Dimensions and Job Performance. 29(1): 68-74.

Rustiarini, N.W. 2013. Pengaruh Kompleksitas Tugas, Tekanan Waktu, dan Sifat Kepribadian pada Kinerja. Makara Human Behavior Studies in Asia, 17(2): 126.

Siew Siew, C., Zen Cheal, C., Hui Zhi, L., Mary, S. and Ying Pei, T. 2018. a Study on the Relationship Between Professional Skepticism Characteristics and Auditors" Fraud Detection in Malaysian Context. International Conference on Business, Accounting, Finance and Economics (BAFE, 2018) Universiti Tunku Abdul Rahman, Kampar, Perak, Malaysia, 4th and 5th, 10(2): 1-15.

Steel, P. 2007. The nature of procrastination: A meta-analytic and theoretical review of quintessential self-regulatory failure. Psychological Bulletin, 133(1): 65-94.

Willie M. Jallah, S. 2020. Enhanced Professional Certification, Professional Skepticism, and Risk Assessment during Financial Statement Audits. (May).

Winantyadi, N. and Waluyo, I. 2014. Pengaruh Pengalaman, Keahlian, Situasi Audit, dan Etika Terhadap Skeptisisme Profesional Auditor (Studi Kasus pada KAP di Provinsi Daerah Istimewa Yogyakarta). Nominal, Barometer Riset Akuntansi dan Manajemen, 3(1). 